\title{
THE INFLUENCE OF LOW-MOLECULAR FRACTION FROM CORD BLOOD (BELOW 5 kDa) ON FUNCTIONAL AND BIOCHEMICAL PARAMETERS OF CELLS IN VITRO
}

\author{
A. K. GULEVSKY, N. N. MOISIEIEVA, O. L. GORINA, \\ J. S. AKHATOVA, A. A. LAVRIK, A. V. TRIFONOVA \\ Institute for Problems of Cryobiology and Cryomedicine, \\ National Academy of Sciences of Ukraine, Kharkiv; \\ e-mail: moiseeva-nataly@rambler.ru
}

The influence of a low-molecular fraction (below $5 \mathrm{kDa}$ ) from the cattle cord blood (CBF) on functional activity of phagocytes, human embryonic fibroblasts, mesenchymal stromal cells and BHK-21 clone 13/04 and PK-15 cells was studied. The low-molecular fraction added to culture medium increases the growth rate of cell cultures. The incubation of leukoconcentrate in the CBF-containing medium results in an increase in phagocytic indices of neutrophils in the presence of a phagocytosis inhibitor-sodium iodoacetate, leading to a significant increase in intracellular glucose content and alkaline phosphatase activity as compared to the control and the reference drug Actovegin ${ }^{\circledR}$.

Key words: cord blood low-molecular fraction, Actovegin ${ }^{\circledR}$, inhibitors of phagocytosis, leukocytes, glucose, alkaline phosphatase, human embryonic fibroblasts, mesenchymal stromal cells, BHK-21 clone 13/04, PK-15 cells.

$\mathrm{D}$ rugs based on cord blood are successfully used at present in complex therapy of diseases of different genesis. This is preconditioned by the fact that cord blood contains a unique balanced complex of specific placental factors, which determine the fetus growth in ontogenesis and regulate its metabolism. Besides, drugs based on low-molecular components of cord blood, which do not possess antigenic and pyrogenic features, exclude side effects in the form of allergic reactions and also the risk of virus diseases and arouse particular interest.

It was shown in the in vivo and in vitro studies conducted earlier by the authors [1-3] that the lowmolecular fraction (below $5 \mathrm{kDa}$ ) from the cattle cord blood (CBF) possessed apparent immunemodulating and reparative effects. In particular, it was determined that injection of CBF accelerated healing of burns and gastric ulcers [4]. It was shown in the experiments in vitro that the low-molecular CBF stimulated the functional activity of human leucocytes [1, 3].

The impact of the low-molecular fraction (below $5 \mathrm{kDa}$ ) from the cattle cord blood on the functional condition of different cell cultures and metabolism of human leucocytes was studied in this work in the in vitro experiments.

\section{Materials and Methods}

The extraction of the fraction containing components with molecular weights below $5 \mathrm{kDa}$ from the cryodestructed whole cattle cord blood was performed by ultrafiltration [5] using a membrane module Sartorius company (Germany). The peptide content in CBF, determined by the method [6], was 9-10 mg per $100 \mathrm{~g}$ of dry weight. Actovegin ${ }^{\circledR}(40 \mathrm{mg} /$ $\mathrm{ml}$ ), the drug produced by Nicomed company (Austria), was used as a reference drug.

The following cell cultures were used in the work: human embryonic fibroblasts (HEF) on the $4^{\text {th }}-6^{\text {th }}$ passages, mesenchymal stromal cells (MSC), obtained from rat bone marrow, BHK-21 clone 13/04 line (kidney of newly-born Syrian hamster) and PK15 line (pig kidney). A standard cultivation condition for cell cultures was addition of $10 \%$ of fetal bovine serum (HyClone) to the media: for HEF medium 199 (FSUE IPVE of M.P. Chumakova of RAMS, Russia), for MSC - mixture (1:1) DMEM and F12 (Sigma-Aldrich, USA), for BHK-21 clone 13/04 and PK-15 - DMEM (Sigma-Aldrich, USA). Seeding concentration were: for HEF $-8-10 \cdot 10^{4}$, for MSC - 0.5-0.6 $10^{4}$, for BHK-21 clone 13/04 - 6-8 $10^{4}$, for PK-15 - 7-9·10 ${ }^{4}$ cells per $1 \mathrm{ml}$ of medium. 
Proliferation of cultures was evaluated by relation of the number of gathered cells to that of seeded ones (index of proliferation). The cell number was counted by the standard laboratory method in the Goryayev chamber.

Adhesion properties of cell cultures were evaluated by two indices: cell attachment and the rate of cells spreading. The cell attachment was determined by counting cells which were not attached $24 \mathrm{~h}$ after seeding [7]. The culture spreading rate was determined by calculation of spindle-shaped cells 1.5; 3; 5 and $24 \mathrm{~h}$ after seeding. Cell monolayer was fixed in the above-mentioned terms, stained by Karachi hematoxylin and $0.1 \%$ eosin solution. The evaluation was performed visually by light microscopy.

To determine mitotic activity of culture, cell monolayer was fixed every $24 \mathrm{~h}$ and stained by Karachi hematoxylin. Mitotic activity was determined by the total number of dividing cells per 1,000 calculated ones. The indiex of mitotic activity (mitotic index - MI) was expressed in per mille (\%) [8]

Leukoconcentrate was obtained from human donor blood by sedimentation of erythrocytes in dextran solution [9]. Phagocyte activity was investigated by the method [10]. To estimate phagocytic activity we used a one-day inactivated Staphylococcus aureus culture, strain no. $209\left(2 \cdot 10^{9} \mathrm{cell} / \mathrm{ml}\right)$, as a phagocytosis item. The following parameters were chosen as indices for estimation of phagocytic activity: percentage of phagocyting neutrophils and monocytes (phagocyte index, PI), average number of engulfed bacteria per one phagocyte (phagocytic number, PN) characterizing engulfing capacity of cells after 45 or 120 minutes of incubation, and index of phagocytosis completeness (IPC) characterizing digestion activity of phagocytes. The index of phagocytosis completeness was calculated as the following fraction: phagocytic number after 45-minute incubation/phagocytic number after 120 minutes incubation. To inhibit phagocyte activity of neutrophils, colchicine $(100 \mu \mathrm{M})$ [11] or sodium iodoacetate (1 mM) [12] was added to suspension of leucocytes. CBF and Actovegin, the reference drug, were added in concentrations of 0.15 and $1.50 \mathrm{mg} /$ $\mathrm{ml}$, respectively [3].

To determine glucose content donor blood leucocytes $\left(2 \cdot 10^{7}\right.$ cells $\left./ \mathrm{ml}\right)$ were preliminarily incubated for $15 \mathrm{~min}$ at $37^{\circ} \mathrm{C}$ in glucose-containing medium $(20 \mathrm{mM})$ with addition of CBF (the final concentration was $0.15 \mathrm{mg} / \mathrm{ml}$ [3]) or Actovegin ${ }^{\circledR}$ (the final concentration was $1.50 \mathrm{mg} / \mathrm{ml}$ [3]). To inhibit glucose transporter GLUT-1, cytochalasin B (10 $\mu \mathrm{M})(\mathrm{Sig}-$ ma-Aldrich, USA) was added to suspension of leucocytes [13]. The method of gel filtration on a column was used to remove extracellular glucose, which is contained in the incubation medium of cells. The cell suspension was further filtered through the column filled up by Sephadex G-25 (Pharmacia, Sweden).

The authors added $30 \mu 1$ of $1 \%$ Triton X-100 solution to cell suspension after filtration and determined glucose content by the glucose oxidase method using a kit of reagents to determine glucose content in biological liquids of Filicit-Diagnostika Company (Ukraine) [10]. Glucose content was expressed in $\mu \mathrm{mol} / 10^{9}$ cells.

To study activity of alkaline phosphatase, leucocytes $\left(3.5 \cdot 10^{7} \mathrm{cell} / \mathrm{ml}\right)$ were preliminarily incubated for $30 \mathrm{~min}$ at $37^{\circ} \mathrm{C}$ in medium with $\mathrm{CBF}$ $(0.15 \mathrm{mg} / \mathrm{ml})$ or with Actovegin $(1.50 \mathrm{mg} / \mathrm{ml})$ in the presence or absence of Staphylococcus. Activity of alkaline phosphatase was determined by spectrophotometry [14]. The choice of incubation period is based on the experimental studies [15] and corresponds to the maximum enzymatic activity during the development of the phagocytic reaction. Alkaline phosphatase activity was determined spectrophotometrically according to the manual of the kit reagents for the determination of alkaline phosphatase activity in biological fluids (Phyllis-Diagnostics, Ukraine) and expressed in $\mu \mathrm{kat} / \mathrm{l}$ of cell lysate (corresponding to $3.5 \cdot 10^{9}$ cell/1) [15]. The experimental data were statistically processed by the non-parametric Mann-Whitney test. The results are presented as $M \pm m$. Significance level was 0.05 .

\section{Results and Discussion}

The growth rate of cell cultures was studied to assess the CBF influence on their functional condition. Influence of different $\mathrm{CBF}$ concentrations on proliferative indices of cell cultures was estimated in the first stage of our work. CBF added to HEF in the concentration of $56 \mu \mathrm{g} / \mathrm{ml}$ stimulated proliferation by $47.6 \%$ after $96 \mathrm{~h}$ of growth and in the concentration of $224 \mu \mathrm{g} / \mathrm{ml}$ - by $78 \%$ (Fig. 1). CBF in the concentration of $56 \mu \mathrm{g} / \mathrm{ml}$ stimulated MSC proliferation after 72 -h cultivation by $13.4 \%$, but in the concentrations of 112 and $224 \mu \mathrm{g} / \mathrm{ml}$ - by $23 \%$ in comparison to the control. At addition of CBF in the concentration of $56 \mu \mathrm{g} / \mathrm{ml}$ the number of BHK-21 clone 13/04 cells exceeded the control by $89 \%$ after $96 \mathrm{~h}$ of incubation, in the concentration of $224 \mu \mathrm{g} / \mathrm{ml}$ 


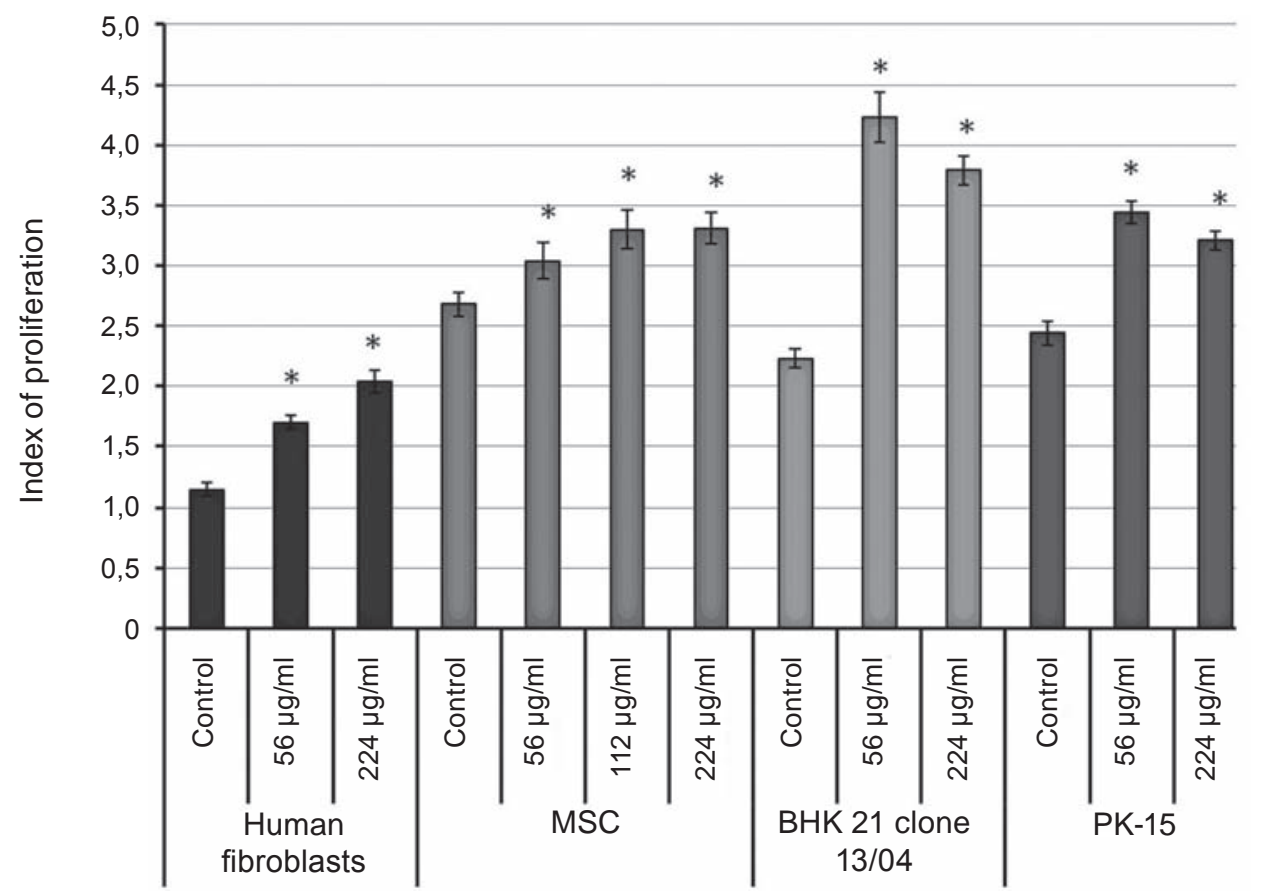

Fig. 1. The proliferative indices of cell cultures after addition of CBF in different concentrations to cultivation media. *Differences are significant in comparison with the corresponding control, $P \leq 0.05$

- by $70 \%$, but in the case of PK-15 line - by $40.5 \%$ and $31.5 \%$, respectively.

The performed studies allowed us to establish the stimulating influence of $\mathrm{CBF}$ on proliferation of cell cultures and to reveal the fact that cells of the cultures studied in this work have different sensibility to CBF addition to cultivation media.

The study of separate growth stages of cell cultures, namely, adhesion and mitotic division of cells, showed the following. The cell attachment of different cultures at CBF addition to the cultivation media remains unchanged (Table 1).

We studied the spreading rate in HEF culture; its cells take a distinct spindle shape when the process is completed. CBF addition in the concentration of $224 \mu \mathrm{g} / \mathrm{ml}$ increased the cell spreading rate. After 3-h cultivation the number of spindle-shaped cells in this variant was higher than in the control by $15.4 \%$, but after 24 -h cultivation - by $13.6 \%$.

Thus, the increase of HEF spreading rate at CBF adding may be related both to the impact on energetic metabolism, which leads to improvement of cells provision with ATP energy, and to stimulation of this process by growth factors.

After reaching their maximal spreading and formation of characteristic morphology, the cells become sensitive to mitogen action [16]. We studied CBF influence on mitotic activity on BHK-21 clone
13/04 line. MI in the variant of CBF addition in the concentration of $56 \mu \mathrm{g} / \mathrm{ml}$ was $30.67 \pm 2.18$ after 24-h cultivation, $56.00 \pm 2.00$ after 48 -h cultivation, and $40.40 \pm 1.66$ after 72 -h cultivation, which exceeded the control values in the above-mentioned terms by 64,55 and $20.5 \%$, respectively. The results obtained show an earlier start of cell mitotic division and increase of culture mitotic activity under $\mathrm{CBF}$ influence. The increase of mitotic activity was also determined for MSC. MI on the peak of mitotic activity (72-h cultivation) under CBF influence was $18.5 \pm 1.7$ that exceeded the control by $28 \%$.

Generalizing the obtained results on CBF influence on the cell culture growth rate, we may draw the following conclusions: CBF accelerates processes of culture adhesion, activates the start of culture mitotic division and stimulates their mitotic activity.

To determine mechanisms of CBF influence on the functional activity of cells the CBF influence on

Table 1. Cell attachment after 24 h of cultivation, \%

\begin{tabular}{l|c|c}
\hline \multicolumn{1}{c|}{ Culture } & Control & with CBF \\
\hline HEF & $59.0 \pm 3.0$ & $63.0 \pm 0.6$ \\
BHK-21 clone 13/04 & $90.2 \pm 0.4$ & $89.0 \pm 0.7$ \\
\hline
\end{tabular}


cell metabolism was studied using inhibitors. CBF impact on phagocyte indices of donor blood leucocytes was determined in our earlier studies in vitro [1]. It was shown that CBF stimulated phagocytic activity of frozen-thawed neutrophils and monocytes in 10 -fold less concentration $(0.15 \mathrm{mg} / \mathrm{ml})$ as compared to Actovegin drug $(1.5 \mathrm{mg} / \mathrm{ml})$.

The phagocyte activity of donor blood neutrophils was studied in vitro in the presence of a phagocytosis inhibitor, cholchicine with the aim to reveal mechanisms of the influence of low-molecular $\mathrm{CBF}$ and the reference drug Actovegin. The results showed that CBF or Actovegin addition did not significantly affect the indices of phagocyte activity of cells decreased under the inhibitor influence. Considering the fact that colchicine disrupts polymerization and reorientation of cytoskeleton micro-tubes, our results permit assuming that $\mathrm{CBF}$ and Actovegin do not renew damaged structures of plasma membrane or cytoskeleton during phagocytosis (Table 2).

It is known that activation of leukocytes induces glycolysis and engagement of cytoplasmatic glycogen pool. Taking into account that glycolysis is one of the main sources of energy, which is necessary for the basic phagocytosis stages, in the next series of experiments we incubated leukocyte concentrate in the presence of a glycolysis inhibitor sodium iodoacetate to clarify mechanisms of CBF and Actovegin influence on energetic metabolism. After adding this inhibitor to the medium of leucocyte incubation, a significant decrease in all the phagocyte indices of neutrophils was observed. CBF or Actovegin addition to the incubation medium containing the inhibitor promoted an increase in the phagocyte activity of neutrophils (Table 3 ).
It may be presumed that this effect is attributed to competition of sodium iodoacetate with lowmolecular components of CBF and Actovegin for binding with active centers of key enzymes of glycolysis. On the other hand, taking into account the data on mechanism of Actovegin action targeted to the activation of glucose transport to cells [17], we studied CBF influence on this process. Our results showed that after cells incubation in the medium with CBF or Actovegin glucose content in leucocytes significant increased 13 and 8.7 times as compared to the appropriate control (Fig. 2).

The obtained results allow us to presume that CBF intensifies energy metabolism of leucocytes through increase in the flow of energetic substrate, the basic one for this type of cells. To determine mechanisms of the CBF effect on glucose accumulation in cells, a series of experiments with using cytochalasin B was conducted. As known, cytochalasin B, in addition to its inhibitory effect on cytoskeleton, is capable of inhibiting the transport of glucose into cells by blocking the glucose transporter family GLUT, namely GLUT-1 and GLUT-2 [18-22]. It should be noted that the major glucose transporter for leukocyte lineage is GLUT-1 [23, 24]. Fig. 2 shows that after treatment of cells with cytochalasin B CBF does not lead to an increase in intracellular glucose content as compared with the control (Cyto B). Incubation of leukocytes in CBF-containing medium without inhibitor contributed to the 13-fold increase in the index relative to the control. Based on this, it can be assumed that the mechanism of action of CBF in glucose accumulation by leukocytes associated with its effects on GLUT transporter family via enhancing their activi-

Ta ble 2. Impact of CBF and Actovegin in the presence of colchicine on indicators of phagocyte activity of neutrophils of leukocytes concentrate

\begin{tabular}{|c|c|c|c|c|c|}
\hline Experimental conditions & $\begin{array}{l}\text { PI, \% (45-min } \\
\text { incubation) }\end{array}$ & $\begin{array}{c}\text { PI, \% } \\
(120-\text { min } \\
\text { incubation) }\end{array}$ & $\begin{array}{l}\text { PN, abs. } \\
\text { unit (45-min } \\
\text { incubation) }\end{array}$ & $\begin{array}{l}\text { PN, abs. unit } \\
\text { (120-min } \\
\text { incubation) }\end{array}$ & IPC, rel. unit. \\
\hline Control & $59.44 \pm 2.18$ & $57.77 \pm 1.24$ & $15.09 \pm 1.11$ & $11.69 \pm 0.84$ & $1.30 \pm 0.03$ \\
\hline Medium with colchicine & $18.04 \pm 1.69 *$ & $17.36 \pm 1.03^{*}$ & $3.07 \pm 0.82 *$ & $6.08 \pm 1.15^{*}$ & $0.47 \pm 0.05^{*}$ \\
\hline $\begin{array}{l}\text { Medium with } \\
\text { colchicine and CBF }\end{array}$ & $20.03 \pm 1.38^{*}$ & $19.54 \pm 1.97^{*}$ & $4.76 \pm 1.03^{*}$ & $7.38 \pm 1.18^{*}$ & $0.61 \pm 0.04^{*}$ \\
\hline $\begin{array}{l}\text { Medium with colchicine } \\
\text { and Actovegin }\end{array}$ & $22.56 \pm 1.80^{*}$ & $20.04 \pm 1.54 *$ & $3.95 \pm 1.02 *$ & $6.42 \pm 1.29 *$ & $0.58 \pm 0.05^{*}$ \\
\hline
\end{tabular}

* Significant difference in comparison to the control values $(P<0.05)$ 
Table 3. Impact of CBF and Actovegin in the presence of sodium iodoacetate on indices of phagocytic activity of neutrophils in leukocyte concentrate

\begin{tabular}{l|c|c|c|c|c}
\hline \multicolumn{1}{c|}{$\begin{array}{c}\text { Experimetal } \\
\text { conditions }\end{array}$} & $\begin{array}{c}\text { PI, \% (45-min } \\
\text { incubation) }\end{array}$ & $\begin{array}{c}\text { PI, \% (120-min } \\
\text { incubation) }\end{array}$ & $\begin{array}{c}\text { PN, abs. } \\
\text { units (45-min } \\
\text { incubation) }\end{array}$ & $\begin{array}{c}\text { PN,abs.units } \\
\text { (120-min } \\
\text { incubation) }\end{array}$ & IPC, rel. unit \\
\hline $\begin{array}{l}\text { Control } \\
\text { Medium with }\end{array}$ & $66.11 \pm 3.31$ & $59.69 \pm 1.75$ & $11.08 \pm 1.29$ & $9.20 \pm 1.31$ & $1.23 \pm 0.05$ \\
$\begin{array}{l}\text { Na iodoacetate } \\
\text { Medium with }\end{array}$ & $44.98 \pm 1.61^{*}$ & $45.46 \pm 3.71^{*}$ & $3.74 \pm 0.64^{*}$ & $6.30 \pm 0.55^{*}$ & $0.58 \pm 0.05^{*}$ \\
$\begin{array}{l}\text { Na iodoacetate } \\
\text { and CBF }\end{array}$ & $56.17 \pm 3.01^{\#}$ & $51.71 \pm 4.44$ & $8.75 \pm 1.01^{\#}$ & $7.30 \pm 1.02$ & $1.22 \pm 0.04^{\#}$ \\
$\begin{array}{l}\text { Medium with } \\
\text { Na iodoacetate } \\
\text { and Actovegin }\end{array}$ & $59.63 \pm 2.83^{\#}$ & $59.58 \pm 2.71^{\#}$ & $9.22 \pm 1.14^{\#}$ & $7.13 \pm 0.72$ & $1.28 \pm 0.04^{\#}$ \\
\hline
\end{tabular}

* Significant difference in comparison with the control values $(P<0.05) ;{ }^{\#}$ Significant difference in comparison with the values of leucocytes incubated with inhibitor $(P<0.05)$

ty, increasing the amount on cell surface or influencing transporter affinity for glucose.

Alkaline phosphatase (AP, 3.1.3.1) is a marker of the functional usefulness of leukocytes. It is contained in specific secondary granules of phagocytes and plays an important role in phagocytosis [25]. It is known that AP is localized in cytoplasm, affects oxidative processes in cells by cleavage of ATP and ADP, dephosphorylation of NADP and NADPH, as well as indirectly regulates glycogen synthesis by dephosphorylation of glycogen [26]. In the light of this information, the activity of this enzyme in lysates of leukocytes was studied. Cells were preincubated in media containing CBF (final concentration $0.15 \mathrm{mg} / \mathrm{ml}$ [3]) or Actovegin (final concentration $1.50 \mathrm{mg} / \mathrm{ml}[3])$.
It was shown that AP activity in the presence of CBF during phagocytosis significantly increased 1.7 times in comparison with the control (Fig. 3, $A$ ). Besides, the reference drug did not influence this enzyme activity.

It should be noted that CBF addition to the incubation medium affects the level of enzymatic activity only in leucocytes stimulated by Staphylococcus (Fig. 3, $A, B$ ). An increase in AP activity after adding CBF points to stimulation of the functional activity of phagocyting cells and correlates with the data on glucose accumulation by leucocytes. These data promote the understanding of mechanisms of CBF influence on the phagocyte activity of neutrophils studied earlier by the authors [1].

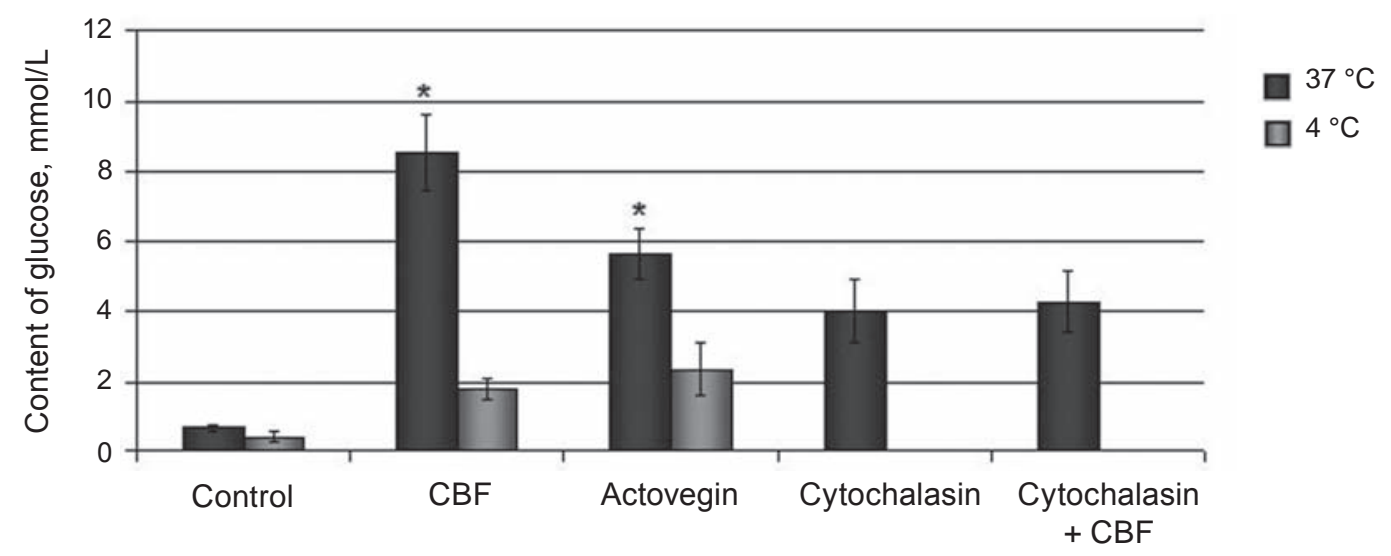

Fig. 2. Glucose content in cells of leucocyte concentrate after incubation in the medium containing CBF or Actovegin. * Significant difference in comparison with the control values, $P<0.05$. 
$A$

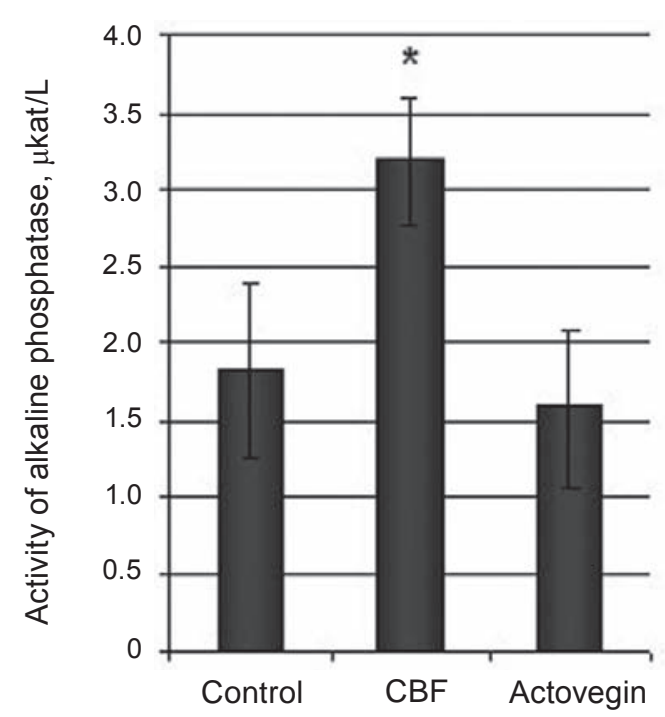

$B$

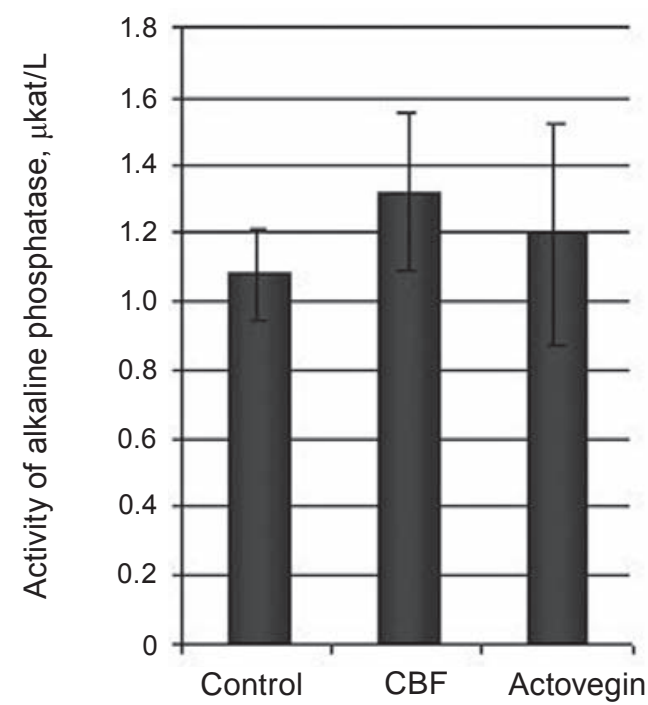

Fig. 3. Influence of CBF and Actovegin on alkaline phosphatase activity of leucocytes during of phagocytosis (A) and at rest (B). * Significant difference in comparison with the control values, $P<0.05$

Thus, as a result of the performed studies it was determined that CBF addition to cultivation medium accelerated the processes of cell culture adhesion, activated the start of mitotic division and stimulated mitotic activity, increasing the rate of their growth. Studying biochemical indices in the process of phagocyte reaction of leucocytes, we observed the increase in AP activity and intracellular concentration of glucose in the medium containing CBF. Thus, the study of the action mechanism of the CBF allows us to suggest that the stimulatory effect of the fraction occurs due to the direct participation of its components in the energy metabolism reactions in the cell, which is one of the factors of increase in the functional status indices of cell cultures HEF, MSC, BHK-21clone 13/04 and phagocytic activity of leukocytes.

\section{ВПЛИВ НИЗЬКОМОЛЕКУЛЯРНОЇ ФРАКЦІЇ 3 КОРДОВОЇ КРОВІ (ДО 5 кДа) НА ФУНКЦІОНАЛЬНІ ТА БІОХІМІЧНІ ПОКАЗНИКИ КЛІТИН У ДОСЛIДАХ IN VITRO}

О. К. Гулевський, Н. М. Моісєєва,

О. Л. Горіна, Ю. С. Ахатова, О. А. Лаврик, А. В. Трифонова

$$
\begin{aligned}
& \text { Інститут проблем кріобіології та } \\
& \text { кріомедицини НАН України, Харків; } \\
& \text { e-mail: moiseeva-nataly@rambler.ru }
\end{aligned}
$$

Досліджено вплив низькомолекулярної (до 5 кДа) фракції з кордової крові (ФКК) великої рогатої худоби на функціональну активність фагоцитів, ембріональних фібробластів людини, мезенхімальних стромальних клітин та клітин BHK-21 clone 13/04 і PK-15. Встановлено, що додавання ФКК в середовище культивування збільшує швидкість росту клітинних культур. 
Інкубація концентрату лейкоцитів у середовищі, що містить ФКК, стимулює збільшення фагоцитарних показників нейтрофілів у присутності інгібітора фагоцитозу йодоацетату натрію, призводить до значимого збільшення внутрішньоклітинного вмісту глюкози та активності лужної фосфатази порівняно 3 контролем та дією препарату «Актовегін».

К л ю ч о в і сл ов а: низькомолекулярна фракція кордової крові, «Актовегін», інгібітори фагоцитозу, лейкоцити, глюкоза, лужна фосфатаза, ембріональні фібробласти людини, мезенхімальні стромальні клітини, BHK-21 clone 13/04, PK-15.

\section{ВЛИЯНИЕ НИЗКОМОЛЕКУЛЯРНОЙ ФРАКЦИИ ИЗ КОРДОВОЙ КРОВИ (ДО 5 КДа) НА ФУНКЦИОНАЛЬНЫЕ И БИОХИМИЧЕСКИЕ ПОКАЗАТЕЛИ КЛЕТОК В ЭКСПЕРИМЕНТАХ IN VITRO}

\section{А. К. Гулевский, Н. Н. Моисеева, \\ О. Л. Горина, Ю. С. Ахатова, А. А. Лаврик, А. В. Трифонова}

\author{
Институт проблем криобиологии и \\ криомедицины НАН Украины, Харьков; \\ e-mail: moiseeva-nataly@rambler.ru
}

Изучено влияние низкомолекулярной (до 5 кДа) фракции из кордовой крови (ФКК) крупного рогатого скота на функциональную активность фагоцитов, эмбриональных фибробластов человека, мезенхимальных стромальных клеток, линий BHK-21clone 13/04 и PK-15.Установлено, что добавление ФКК в среду культивирования увеличивает скорость роста клеточных культур. Инкубация концентрата лейкоцитов в среде, содержащей ФКК, повышает фагоцитарные показатели нейтрофилов в присутствии ингибитора фагоцитоза йодоацетата натрия, приводит к достоверному увеличению внутриклеточного содержания глюкозы и активности щелочной фосфатазы по сравнению с контролем и препаратом сравнения «Актовегин».

К л ю ч е в ы е с л о в а: низкомолекулярная фракция кордовой крови, «Актовегин», ингибиторы фагоцитоза, лейкоциты, глюкоза, щелочная фосфатаза, эмбриональные фибробласты человека, мезенхимальные стромальные клетки, BHK-21 clone 13/04, PK-15.

\section{References}

1. Gulevsky A. K., Gorina O. L., Moiseyeva N. N., Stepanyuk L. V. Stimulatory effects of the cord blood low-molecular fraction (below $5 \mathrm{kDa}$ ) and Actovegin on phagocytic activity of cryopreserved leukocytes. Ukr. J. Hematol. Transfusiol. 2010;(1):22-29. (In Ukrainian).

2. Moiseyeva N. N. The influence of a low molecular fraction (less then $5 \mathrm{kD}$ ) from cord blood on regeneration process in burn wounds in rats. World Biol. Med. 2009;(3):117-120. (In Ukrainian).

3. Gulevsky A. K., Moiseyeva N. N., Gorina O. L. Influence of low-molecular (below $5 \mathrm{kDa}$ ) fraction from cord blood and actovegin on phagocytic activity of frozen-thawed neutrophils. CryoLetters. 2011;32;(2):131-140.

4. Gulevsky A. K., Abakumova E. S., Moiseyeva N. N., Dolgih O. L. Influence of fraction from cattle cord blood on biochemical parameters in experimental subchronic gastric ulcer in rats (below $5 \mathrm{kDa}$ ). Ukr. Biokhim. Zhurn. 2008;80(2):92-99. (In Ukrainian).

5. Brock T. D. Membrane Filtration [ed. B. V. Mchedlishvili]. M.: Mir, 1987. 464 p. (In Russian).

6. Practical Protein Chemistry [ed. A. Darbre]. M.: Mir, 1989. 623 p. (In Russian).

7. Basic Cell Culture. Practical Approach. Second edition. Ed. J. M. Davis. Oxford: University Press, 2001. $381 \mathrm{p}$.

8. Blyumkin V. N., Zhdanov V. M. Effect of viruses on the chromosome apparatus and cell division. M .: Medicine, 1973. 267 p. (In Russian).

9. Grishina V. V., Timokhina E. V., Andreeva L. Yu. Collection system and fractionation cord blood stem cells. Questions Gynecol. Obstet. Perinatol. 2004;3(6):50-54. (In Russian).

10. Tietz N. U. Encyclopedia of clinical laboratory tests [ed. V. V. Menshikov]. M.: Labinform, 1997. 960 p. (In Russian).

11. Tsai M. A., Waugh R. E., Keng P. C. Passive mechanical behavior of human neutrophils: effects of colchicine and paclitaxel. Biophys. $J$. 1998;74(6):3282-3291.

12. D'Onofrio C. Paradisi F., Piccolo D. The influence of some metabolic inhibitors on in vitro phagocytizing macrophages. I. The behaviour of human macrophages. Med. Microbiol. Immunol. 1977;163(3):195-207. 
13. Wood T. E., Dalili S., Simpson C. D., Hurren R., Mao X., Saiz F. S., Gronda M., Eberhard Y., Minden M. D., Bilan P. J., Klip A., Batey R. A., Schimmer A. D. A novel inhibitor of glucose uptake sensitizes cells to FAS-induced cell death. Mol. Cancer Ther. 2008;7(11):3546-3555.

14. Burtis C. A., Ashwood E. R. Tietz Textbook of Clinical Chemistry, $2^{\text {nd }}$ edition. Amer. Assn for Clinical Chemistry, 1994. P. 2370.

15. Bainton D. F. Sequential degranulation of the two types of polymorphonuclear leukocyte granules during phagocytosis of microorganisms. J. Cell Biol. 1973;58(5):249-264.

16. Mushkambarov N. N., Kuznetsov S. L. Molecular biology: a textbook for medical students. M.: Medical Information Agency, 2003. 544 p. (In Russian).

17. Rumyantseva S. A. Actovegin. New aspects of clinical application. M., 2002. 280 p. (In Russian).

18. Ulanovskaya O. A., Cui J., Kron S. J., Kozmin S. A. A pairwise chemical genetic screen identifies new inhibitors of glucose transport. Chem. Biol. 2011;18(2):222-230.

19. Blodgett D. M., Graybill C., Carruthers A. Analysis of glucose transporter topology and structural dynamics. J. Biol. Chem. 2008;283(52):36416-36424.

20. Estensen R. D., Plagemann P. G. W. Cytochalasin B: Inhibition of glucose and glucosamine transport. Proc. Nat. Acad. Sci. USA. 1972;69(6):1430-1434.

21. Hebert D. N., Carruthers A. Glucose transporter oligomeric structure determines transporter function. J. Biol. Chem. 1992;267(33):2382923838.

22. Salas-Burgos A., Iserovich P., Zuniga F., Vera J. C., Fischbarg J. Predicting the threedimensional structure of the human facilitative glucose transporter Glut1 by a novel evolutionary homology strategy: insights on the molecular mechanism of substrate migration, and binding sites for glucose and inhibitory. Biophys. J. 2004;87(5):2990-2999.

23. Gulevsky A. K., Veselovskaya Yu. S. Modern views on the energy metabolism of leukocytes. Ukr. J. Hematol. Transfusiol. 2011;(6):5-18. (In Ukrainian).

24. Schuster D. P., Brody S. L., Zhou Z., Bernstein M., Arch R., Link D., Mueckler M. Regulation of lipopolysaccharide-induced increases in neutrophil glucose uptake. Am J. Physiol Lung Cell Mol. Physiol. 2007;292(4):845-851.

25. Nazarenko G. I., Kiskun A. A. Clinical evaluation of laboratory results. M.: Medicine, 2007. 544 p. (In Russian).

26. Shubich M. G, Nagoev B. S. Leukocyte alkaline phosphatase in health and disease. M.: Medicine, 1980. 224 p. (In Russian).

Received 29.10.2013 